\title{
PENITIPAN GANTI RUGI PEMEGANG HAK DALAM PENGADAAN TANAH PEMBANGUNAN JALAN TOL BATANG
}

\author{
Nurazima Faizrosadi, Pujiyono, Irma Cahyaningtyas \\ Program Studi Magister Kenotariatan, \\ Fakultas Hukum Universitas Diponegoro \\ E-mail :faizrosadi.FR@gmail.com
}

\begin{abstract}
The background in the construction of toll roads in Batang Regency is based on Law Number 2 of 2012 concerning Land Procurement for Development in the Public Interest, there are holders of land rights who do not want land acquisition so that compensation payments take place at the District Court (Consignment). Research is determinelegal protection land rights holderscompensation is consigned and know legal consequences of rights holders in the process of land acquisition for toll roads in Batang Regency. Research method is empirical juridical, analyzing the problem, applicable regulations with legal theory, and implementing object. Results of study, the implementation of land acquisition for toll roads in Batang Regency based on Law Number 2 of 2012 concerning Land Procurement for Development in the Public Interest. Residents who refused the amount of compensation, so submitted a letter requesting for compensation to the Batang District Court. Conclusion, legal consequences of holders of land rights are they can a lawsuit in district court and land belongs to the state, and legal protection in aspect of human rights does not guarantee legal protection, but land law has been regulated to obtain land. anyone and with the principles of agreement, humanity, and justice.
\end{abstract}

\section{Keywords : consignment; land acquisition; toll road}

\begin{abstract}
Abstrak
Latar belakang dalam pembangunan jalan tol di Kabupaten Batang didasarkan pada UndangUndang Nomor 2 Tahun 2012 tentang Pengadaan Tanah Bagi Pembangunan Untuk Kepentingan Umum, ada pemegang hak atas tanah yang tidak mau dilakukan pengadaan tanah sehingga terjadi penitipan ganti rugi di Pengadilan Negeri (Konsinyasi). Tujuan penelitian untuk mengetahui perlindungan hukum terhadap pemegang hak atas tanah yang ganti ruginya dikonsinyasikan dan mengetahui pelaksanaan ganti rugikepada para pemegang hak dalam proses pengadaan tanah untuk jalan tol di Kabupaten Batang. Metode penelitian adalah yuridis empiris, yaitu menganalisis permasalahan, mengaitkan peraturan yang berlaku dengan teori hukum, dan pelaksanaan objek penelitian. Berdasarkan hasil penelitian, pelaksanaan pengadaan tanah untuk jalan tol di Kabupaten Batang dilaksanakan berdasarkan Undang-Undang Nomor 2 Tahun 2012 tentang Pengadaan Tanah Bagi Pembangunan Untuk Kepentingan Umum. Terdapat warga yang menolak besarnya ganti rugi, sehingga panitia mengajukan surat permohonan penitipan ganti rugi ke Pengadilan Negeri Batang. Kesimpulannya konsekuensi yuridis pemegang hak atas tanah adalah dapat mengajukan gugatan ke pengadilan negeri serta tanah mereka menjadi milik negara, dan perlindungan hukum dalam aspek hak asasi manusia kurang menjamin adanya perlindungan hukum, namun dalam hukum pertanahan sudah mengaturnya untuk memperoleh tanah tidak dibenarkan adanya paksaan oleh pihak siapapun dan dengan asas kesepakatan, kemanusiaan, dan keadilan.
\end{abstract}

Kata kunci : konsinyasi; pengadaan tanah; jalan tol 


\section{A. Pendahuluan}

Tanah merupakan suatu hal yang penting bagi setiap kehidupan manusia. Hal ini karena setiap pembangunan yang dilakukan oleh Negara maupun masyarakat sendiri selalu didirikan diatas tanah. Bahkan seringkali ada bangunan yang dibangun diatas tanah konflik atau dengan kata lain terjadi konflik dalam pembangunan antara pihak pemerintah dengan pihak masyarakat. Apabila ingin memanfaatkan tanah masyarakat yang akan dipakai untuk kepentingan umum maka dilakukan pengadaan tanah yang dilakukan oleh pemerintah dengan cara pelepasan dan penyerahan hak.

Penerapan hukumnya terkadang tidak memuaskan oleh sebagian besar masyarakat. Meskipun penerapan hukum tersebut didasarkan pada hukum normatif yang telah berupa Undang-Undang. Menentukan hak atas sebidang tanah, siapa penghuni pertama menjadi faktor yang menentukan. Kepemilikan tanah merupakan sebuah hak asasi manusia yang dilindungi oleh hukum internasional maupun hukum nasional. Pengaturannya di hukum internasional, perlindungan hukum hak milik diatur dalam DUHAM (Deklarasi Hukum Hak Asasi Manusia) Pasal 17.1, Pasal 17.2, Pasal 25.1, dan Pasal 30. Hukum nasional, perlindungan hukum hak milik diatur dalam Undang-Undang Dasar Tahun 1945 Pasal 28 H ayat (4)(Undang-Undang Dasar Negara Republik Indonesia, 1945), dan Undang-Undang Nomor 39 Tahun 1999 tentang Hak Asasi Manusia(Limbong, 2011).

Pada prinsipnya, dasar yuridis dari pengadaan tanah untuk kepentingan umum mengacu pada Pasal 18 Undang-Undang Nomor 5 Tahun 1960 tentang Peraturan Dasar Pokok-pokok Agraria: "Untuk kepentingan umum,termasuk kepentingan bangsa dan negara serta kepentingan bersama dari rakyat, hak-hak atas tanah dapat dicabut, dengan memberikan ganti kerugian yang layak dan menurut cara yang diatur dengan Undang-Undang”(Limbong, 2011).

Pengertian pengadaan tanah sendiri telah tercantum di dalam Undang-Undang Nomor 2 Tahun 2012 Pasal 1 butir(2) yang berbunyi: "Pengadaan tanah adalah kegiatan menyediakan tanah dengan cara member ganti kerugian yang layak dan adil kepada pihak yang berhak"(Undang-Undang Nomor 2 Tahun 2012 tentang Pengadaan Tanah Bagi Pembangunan Untuk Kepentingan Umum, 2012). Hukum tanah merupakan salah satu hukum yang menyentuh hidup orang banyak. Berbagai kasus yang berkaitan dengan tanah seperti pengadaan tanah untuk kepentingan umum juga memerlukan perhatian khusus dari hukum sebagai penegak keadilan (Andorra, 2016)

Peristiwa yang menyangkut tanah erat kaitannya dengan kehidupan manusia. Orang akan mempertahankan tanahnya apabila hak kepemilikannya digangguoleh pihak lain. Padahal berdasarkan ketentuan yang terkandung dalam Pasal 6 Undang-Undang Nomor 5 tahun 1960 
tentang Peraturan Dasar Pokok-Pokok Agraria berbunyi: "Semua hak atas tanah mempunyai fungsi sosial"'(Undang-Undang Pokok Agraria Nomor 5 tahun 1960 tentang Peraturan Dasar Pokok-Pokok Agraria, 1960). Tujuan pemerintah dalam rangka meningkatkan kualitas hidup manusia (mewujudkan kesejahteraan rakyat), maka pembangunan merupakan sebuah keharusan. Demi melaksanakan tujuan pembangunan, pemerintah memerlukan tanah sebagai tempat kegiatan proyek yang akan dibangun. Namun, berbagai permasalahan yang berkaitan dengan pengadaan tanah pada umumnya timbul karena ketidaksesuaian ganti rugi yang menyebabkan kesepakatan dari pemerintah dan masyarakat menjadi terhambat. Prosedurnya sebenarnya pada masa ke masa sekarang lebih baik dibandingkan dengan sebelumnya tidak begitu banyak masalah, namun kesulitan prinsipil berada pada kultur yang tumbuh dalam masyarakat. Faktor tersebut dikarenakan masih banyak masyarakat yang menganggap bahwa hak atas tanah adalah hak mutlak sehingga pemilik tanah berhak menentukan sendiri besarnya nilai ganti rugi. Selain melakukan musyawarah agar terjadi kesepakatan antara pemerintah dengan masyarakat, maka harus adanya rasa kerelaan kepentingan masing-masing dimana dalam hal ini pemerintah harus memberikan ganti rugi yang layak sedangkan masyarakat harus merelakan tanahnya untuk digunakan dalam pembangunan untuk kepentingan umum dan tidak menuntut ganti rugi yang tinggi. Berbagai sengketa pertanahan itu telah mendatangkan berbagai dampak baik secara ekonomi, sosial, dan lingkungan.

Macam-macam hak lain selain hak milik yakni hak guna bangunan, hak guna usaha, hak pakai, dan hak pengelolaan memiliki batas masa berlakunya, berdasarkan hal tersebut dapat disimpulkan bahwa hanya hak milik yang dapat diwakafkan karena hak milik tidak memiliki masa berlaku dan merupakan hak terkuat. Demikian menurut aturan hukum agraria kita (Hermit, 2007).

Secara ekonomis, sengketa itu telah memaksa pihak yang terlibat untuk mengeluarkan biaya. Semakin lama proses penyelesaian sengketa itu, maka semakin besar biaya yang harus dikeluarkan. Dampak sosial dari konflik adalah terjadinya kerenggangan sosial diantara warga masyarakat, termasuk hambatan bagi terciptanya kerja sama di antara mereka. Apabila terdapat konflik yang terjadi antar instansi pemerintah, hal itu akan menghambat terjadinya koordinasi kinerja publik yang baik. Dapat juga terjadi penurunan tingkat kepercayaan masyarakat terhadap pemerintah berkenaan pelaksanaan tata ruang. Selama konflik berlangsung, ruang atas wilayah dan atas tanah yang menjadi objek konflik biasanya berada dalam status quo sehingga ruang atas tanah yang bersangkutan tidak dapat dimanfaatkan. Akibatnya adalah terjadinya penurunan kualitas sumber daya lingkungan yang dapat merugikan kepentingan banyak pihak(Sumardjono, Maria S.W dan Ismail, 2008). Pengertian hak atas tanah lainnya adalah hak- 
hak atas tanah sebagaimana ditetapkan Pasal 16 Undang-Undang Nomor 5 Tahun 1960 tentang Peraturan Dasar Pokok-Pokok Agraria yang meliputi hak milik, hak guna usaha, hak guna bangunan, dan hak pakai. khususnya hak atas tanah primer (originair) yaitu hak atas tanah yang langsung diberikan oleh negara kepada subjek hak(Chomzah, 2002).

Secara umum proses pengadaan tanah dilakukan secara musyawarah dengan ganti rugi oleh tim appraisal (lembaga penilai harga tanah), masing-masing pihak setuju dan diikuti dengan pelepasan hak atas tanahnya dari pemilik tanah kepada instansi pemerintah. Namun apabila tidak terjadi kesepakatan maka akan dikonsinyasi yang menimbulkan permasalahan terkait pelepasan hak atas tanahnya. Kejadian ini terjadi di Kota Batang pada kasus pembangunan jalan tol kota Batang-Semarang, dimana terdapat warga yang tidak sepakat dalam pemberian ganti rugi, maka pemerintah menitipkan uang ganti kerugian tersebut di pengadilan negeri setempat. Dipengaruhi oleh faktor itu, maka muncul anggapan bahwa pemerintah mengupayakan kesediaan masyarakat untuk melepaskan hak atas tanahnya dengan kata lain masyarakat wajib melepaskan hak atas tanahnya. Permasalahan-permasalahan yang terkait dengan pengadaan tanah, berorientasi pada kepastian hukum tentang letak dan luas tanah yang dibutuhkan, jenis hak atas tanah yang ada di atas tanah objek pengadaan tanah, serta besar uang ganti kerugian (Permatasari, 2019). Persoalan-persoalan yang mengganggu pelaksanaan pengadaan tanah tersebut, hendaknya tidak dibiarkan berlangsungterus tanpa ada penyelesaian. Akan tetapiharus dicari upaya pemecahan masalahnya,sehingga tercipta ketenteraman di masyarakat.Dari berbagai penjelasan diatas, peneliti tertarik melakukan penelitian yang terletak di Kota Batang karena kota tersebut termasuk dalam perencanaan proyek pembangunan jalan tol Trans Jawa yang menjadi program pemerintahan era presiden Joko Widodo yang terkait tata guna lahan.

Teori digunakan untuk menganalisis permasalahan pada artikel ini diantaranya adalah:

\section{Teori Perlindungan Hukum}

Menurut Fitzgerald sebagaimana dikutip Satjipto Raharjo awal mula darimunculnya teori perlindungan hukum ini bersumber dari teori hukum alam ataualiran hukum alam. Menurut aliran hukum alam menyebutkan bahwa"hukum itu bersumber dari Tuhan yang bersifat universal dan abadi, serta antarahukum dan moral tidak boleh dipisahkan. (Raharjo, 2000). Para penganut aliran ini memandangbahwa hukum dan moral adalah cerminan dan aturan secara internal dan eksternaldari kehidupan manusia yang diwujudkan melalui hukum dan moral".

Fitzgerald menjelaskan teori perlindungan hukum Salmond bahwa hukumbertujuan mengintegrasikan dan mengkoordinasikan sebagai kepentingan dalammasyarakat karena 
dalam suatu lalu lintas kepentingan, perlindungan terhadapkepentingan tertentu hanya dapat dilakukan dengan cara membatasi berbagai kepentingan di lain pihak. Satjipto Rahardjo mengemukakan bahwa, perlindungan hukum adalah adanya upaya melindungi kepentingan seseorang dengan cara mengalokasikan suatu kekuasaan kepadanya untuk bertindak dalam kepentingan tersebut. selanjutnya dikemukakan pula bahwa salah satu sifat dan sekaligus merupakan tujuan dari hukum adalah memberikan perlindungan (pengayoman) kepada masyarakat (Raharjo, 2004).

Menurut pendapat Philipus M. Hadjon bahwa perlindungan hukum bagi rakyat sebagai tindakan pemerintah yang bersifat preventif dan represif.Perlindungan hukum yang preventif dan represif. Perlindungan hukum yangpreventif bertujuan untuk mencegah terjadinya sengketa, yang mengarahkantindakan pemerintah bersikap hati-hati dalam pengambilan putusan berdasarkandiskresi. Perlindungan yang represif bertujuan untuk menyelesaikan terjadinyasengketa, termasuk penanganan di lembaga peradilan (Hadjon, 1987).

Perlindungan hukum yang diberikan bagi rakyat Indonesia merupakanimplementasi atas prinsip pengakuan dan perlindungan terhadap harkat danmartabat manusia yang bersumber pada pancasila dan prinsip negara hukum yangberdasarkan pancasilla. Setiap orang berhak mendapatkan perlindungan darihukum. Hampir seluruh hubungan hukum harus dapat perlindungan dari hukum.Oleh karena itu, terdapat banyak macam perlindungan hukum.

Perlindungan hukum bagi rakyat meliputi dua hal, yakni : (Mertokusumo, 2010)

a. Perlindungan hukum preventif, yakni bentuk perlindungan hukum dimana kepada rakyat diberi kesempatan untuk mengajukan keberatan atau pendapat sebelum keputusan pemerintah mendapat bentuk yang defenitif.

b. Perlindungan hukum represif, yakni bentuk perlindungan hukum melalui Pengadilan guna menyelesaikan sengketa.

2. Teori Keadilan

Pada dasarnya keadilan merupakan prinsip dari kebijakan rasional yang diaplikasikan untuk konsepsi jumlah dari kesejahteraan seluruh kelompok dalam masyarakat. Untuk mencapai keadilan, maka rasional jika seseorang memaksakanpemenuhan keinginannya sesuai dengan prinsip kegunaan, karena dilakukan untuk memperbesar keuntungan bersih dari kepuasan yang akan diperoleh oleh anggota masyarakatnya.

Prinsip keadilan dipilih karena mengadopsi ide yang lebih realistis dalam menyusun aturan sosial di atas prinsip saling menguntungkan, yang akan meningkatkan efektifitas 
kerja sama sosial. Dalam konsepsi keadilan sebagai kewajaran (justice of fairness), ditemukan kumpulan prinsip-prinsip yang saling berhubungan untuk mengidentifikasi pertimbangan-pertimbangan yang relevan dan menentukan keseimbangan (Rawls, 1971). Justice of fairness lebih memiliki ide yang lebih umum dan lebih pasti, karena prinsipprinsip keadilan (principles of justice) sudah dipilih dan sudah diketahui umum. Hal ini berbeda dengan prinsip kegunaan (principle of utility), dimana makna konsep keadilan diambil dari keseimbangan yang tepat antara tuntutan-tuntutan persaingan. Prinsip kegunaan dapat dilihat dari 2 (dua) sisi. Pertama, bahwa masyarakat yang teratur merupakan pola dari kerja sama untuk memperoleh keuntungan timbal balik yang diatur oleh prinsip-prinsip yang dapat dipilih dalam situasi awal sebagai sesuatu yang wajar. Kedua, sebagai efesiensi administrasi dari sumber-sumber sosial untuk memaksimalkan kepuasan dari sistem dari keinginan yang dikonstruksikan oleh pengamat yang netral.

Berdasarkan latar belakang tersebut, maka rumusan masalah dan tujuan penulisan artikel ini yaitu pertama, bagaimana kebijakan peraturan pengadaan tanah untuk kepentingan umum di Indonesia dan kedua, bagaimana perlindungan hukum terhadap pemegang hak atas tanah yang tanahnya diberikan ganti rugi melalui penitipan di pengadilan (konsinyasi) dalam pembangunan jalan tol di Kabupaten Batang.

Artikel ini menelaah sumber informasi baik dari buku, undang-undang atau penelitian terdahulu yang dijadikan sumber informasi dan perbandingandalam mendapatkan jawaban atas permasalahan-permasalahan tersebut. Beberapa penelitian yang sudah ada dan relevan dengan pembahasan penulisan artikel jurnal,antara lain artikel jurnal yang ditulis oleh Muhammad Yusrizal yang berjudul "Perlindungan Hukum Pemegang Hak Atas Tanah Dalam Pengadaan Tanah Untuk Kepentingan Umum" yang berfokus pada kajian kebijakan peraturan dan perlindungan hukum bagi pemegang hak atas tanah untuk kepentingan umum berdasarkan Undang-Undang dan membahas kebijakan peraturan dan perlindungan hukum bagi pemegang hak atas tanah untuk kepentingan umum berdasarkan Undang-Undang Nomor 2 tahun 2012 tentang Pengadaan Tanah Bagi Pembangunan Untuk Kepentingan Umum (Yusrizal, 2017), artikel jurnal yang ditulis oleh Rizki Yuni Wulandari yang berjudul "Pengadaan Tanah dan Pelaksanaan Pemberian Ganti Rugi Untuk Proyek Pembangunan Pasar Kebon Roek Di Kota Mataram” yang berfokus pada pelaksanaan pengadaan tanah bagi pembangunan untuk kepentingan umum pada proyek pembangunan Pasar Kebon Roek di Kota Mataram dilihat dari Undang-Undang Nomor 2 Tahun 2012 tentang Pengadaan Tanah Bagi Pembangunan Untuk Kepentingan Umum dan Pelaksanaan Ganti Rugi yang dinilai dari segi keadilan (Wulandari, 2018), dan artikel jurnal yang ditulis oleh Mia 
Permatasari yang berjudul "Penyelesaian Sengketa Pengadaan Tanah Guna Pembangunan Bandar Udara Internasional Berbasis Nilai Keadilan Sosial" yang berfokus pada pelaksanaan penyelesaian sengketa dalam pengadaan tanah pada pembangunan proyek Bandar Udara Internasional yang dikaji dari segi keadilan peraturan perundang-undangan yang berlaku (Permatasari, 2019).

Dari perbandingan artikel jurnal tersebut meskipun sama-sama meninjau mengenai pengadaan tanah namun artikel ini mengkaji dan berfokus konsekuensi yuridis dan perlindungan hukum yang diterima oleh pemegang hak atas tanah dalam proses pelaksanaan pengadaan tanah bagi pembangunan untuk kepentingan umum pada pembangunan jalan tol di Kabupaten Batang.

\section{B. Metode Penelitian}

Metode penelitian dalam artikel ini adalah metode yuridis empiris. Yuridis mengandung makna bahwa penelitian ini dianalisis menggunakan berbagai buku, peraturan perundangundangan di bidang agraria sebagai data sekunder. Makna empiris yaitu bertujuan untuk memperoleh pengetahuan tentang hubungan masyarakat dengan hukum yang masih berlaku saat ini dan faktor-faktor yang mempengaruhi pelaksanaan hukum di masyarakat. Pendekatan empiris bahwa penelitian dilakukan dengan melihat kenyataan yang ada dalam praktek (Soekanto, 1986). Jadi metode Yuridis Empiris dalam artikel ini meninjau dan melihat serta menganalisis permasalahan yang menjadi objek artikel yaituKonsekuensi Yuridis Penitipan Uang Ganti Rugi Di Pengadilan (Konsinyasi) Terhadap Pemegang Hak Atas Tanah Dalam Pengadaan Tanah (Studi Kasus Pembebasan Tanah Untuk Pembangunan Jalan Tol Di Kabupaten Batang.Metode yang digunakan dalam menganalisis dan mengolah data-data adalah analisis kualitatif. Analisis kualitatif pada hakikatnya menekankan pada metode deduktif sebagai pegangan utama dan metode induktif sebagai tata kerja penunjang. Analisis kualitatif terutama menggunakan bahan-bahan kepustakaan sebagai sumber penelitiannya.

\section{Hasil Dan Pembahasan}

\section{Kebijakan Peraturan Pengadaan Tanah Untuk Kepentingan Umum Di Indonesia}

Kegiatan pengadaan tanah untuk kepentingan umum dalam rangka pembangunan jalan tol tersebut terdapat kendala yang dihadapi oleh Panitia Pelaksana Pengadaan Tanah (PPT) dan dibantu oleh pegawai kantor Pejabat Pembuat Komitmen (PPK). Salah satu diantaranya yaitu terdapat beberapa pihak yang tanahnya tidak mau dilakukan pencabutan hak dengan alasan tanah tersebut adalah hak milik mereka, padahal dalam Pasal 6 Undang- 
Undang Nomor 5 Tahun 1960 tentang Peraturan Dasar Pokok-Pokok Agraria menyebutkan bahwa "Semua hak atas tanah mempunyai fungsi sosial". Maksud dari fungsi sosial disini adalah bahwa segala hak atas tanah digunakan sebesar-besarnya untuk kesejahteraan warga Negara Indonesia sehingga tanah milik masyarakat khususnya warga negara Indonesia dapat diambil alih hak kepemilikannya oleh negara. Berdasarkan hal tersebut tim PPT dengan para pihak terkait yang telah melakukan musyawarah kepada para warga berdasarkan ketentuan Pasal 42 Undang-Undang Nomor 2 Tahun 2012 tentang Pengadaan Tanah Bagi Pembangunan Untuk Kepentingan Umum melakukan kegiatan penitipan uang ganti rugi (konsinyasi) yang dititipkan di Pengadilan Negeri setempat. Sehingga konsekuensi yang diterima oleh para pemegang hak atas tanah yaitu tanah mereka menjadi milik negara, namun para pemegang hak atas tanah juga dapat mengajukan gugatan keberatan ke pengadilan negeri terkait dengan penetapan nilai ganti rugi yang menurut rumusan Pasal 1 angka (10) Undang-Undang Nomor 2 Tahun 2012 adalah penggantian yang layak dan adil kepada pihak yang berhak dalam proses pengadaan tanah. Penetapan besarnya nilai ganti rugi dalam pengadaan tanah bagi pembangunan untuk kepentingan umum dilakukan oleh Ketua Pelaksana Pengadaan Tanah berdasarkan hasil penilaian jasa penilai/penilai publik (Pasal 63 ayat (1) Peraturan Presiden Nomor 99 Tahun 2014 tentang Perubahan Kedua Atas Peraturan Presiden Nomor 71 Tahun 2012 tentang Penyelenggaraan Pengadaan Tanah Bagi Pembangunan Untuk Kepentingan Umum).

Sebelum para pihak pemegang hak atas tanah melakukan gugatan ke pengadilan negeri, Panitia Pelaksana Pengadaan Tanah melaksanakan musyawarah dengan pihak yang berhak dalam waktu 30 (tiga puluh) hari sejak diterimanya hasil penilaian dari penilai, selanjutnya hasil kesepakatan dari musyawarah tersebut menjadi dasar pemberian ganti rugi kepada pihak yang berhak yang dimuat dalam berita acara kesepakatan (Pasal 37 UndangUndang No 2 Tahun 2012). Apabila dalam hal tidak tercapai kesepakatan mengenai bentuk dan besarnya ganti rugi, pihak yang berhak dapat mengajukan keberatan kepada Pengadilan Negeri setempat dalam jangka waktu 14 (empat belas) hari setelah musyawarah penetapan ganti rugi, selanjutnya Pengadilan Negeri akan memutus dalam waktu paling lama 30 (tiga puluh) hari sejak diterimanya pengajuan keberatan. Apabila pihak yang berhak menolak terhadap putusan Pengadilan Negeri tersebut, maka dalam jangka waktu 14 (empat belas) hari pihak yang berhak dapat mengajukan kasasi ke Mahkamah Agung, selanjutnya Mahkamah Agung wajib memberikan Putusan dalam waktu paling lama 30 (tiga puluh) hari sejak permohonan kasasi diterima. Putusan kasasi yang telah berkekuatan hukum tetap 
tersebut menjadi dasar pemberian ganti rugi kepada pihak yang berhak (Pasal 38 UndangUndang Nomor 2 Tahun 2012).

Penitipan ganti rugi melalui pengadilan bersumber pada ketentuan Undang-Undang Nomor 2 Tahun 2012 berikut peraturan pelaksanaannya. Berdasarkan Pasal 42 dan Pasal 43 Undang-Undang Nomor 2 Tahun 2012 tentang Pengadaan Tanah Bagi Pembangunan Untuk Kepentingan Umum dalam hal pihak yang berhak menolak bentuk dan/atau besarnya ganti rugi berdasarkan hasil musyawarah sebagaimana diatur dalam Pasal 37, atau Putusan Pengadilan Negeri/Mahkamah Agung sebagaimana dimaksud Pasal 38, ganti rugi dititipkan di Pengadilan Negeri setempat. Penitipan ganti rugi juga dapat dilakukan terhadap:

1. Pihak yang berhak menerima ganti rugi tidak diketahui keberadaannya.

2. Objek pengadaan tanah yang akan diberikan ganti rugi sedang menjadi objek perkara di Pengadilan, masih dipersengketakan kepemilikkannya, diletakkan sita oleh pejabat yang berwenang atau menjadi jaminan di bank.

Berdasarkan keterangan dari Kepala Seksi Pengadaan Tanah BPN Darmaji, landasan yuridis dalam pelaksanaan konsinyasi didasarkan pada Undang-Undang Nomor 2 Tahun 2012 tentang Pengadaan Tanah Bagi Pembangunan Untuk Kepentingan Umum yang cenderung bersifat memaksakan kepada warga untuk menyerahkan kepemilikan hak atas tanahnya. Terdapat pula warga yang terpengaruh oleh LSM setempat sehingga menimbulkan rasa curiga terhadap penggunaan tanah mereka yang nantinya akan digunakan untuk kepentingan umum karena permasalahan mengenai penitipan ganti rugi (konsinyasi) dianggap merupakan permasalahan yang sangat sensitif bagi warga setempat. Penetapan nilai ganti rugi sudah ditetapkan oleh Ketua Pelaksana Pengadaan Tanah (PPT) berdasarkan hasil penilaian jasa penilai, jadi dalam musyawarah yang dilakukan oleh tim PPT dengan warga sekitar membahas mengenai bentuk ganti ruginya bukan mengenai nilai ganti ruginya. Menurut Darmaji, pihak BPN hanya bersifat menyetujui tentang permasalahan tanah yang akan dikonsinyasikan dan menghadiri tanah yang akan di eksekusi yang sifatnya formalitas, sedangkan dalam praktek pelaksanaan di lapangan hingga masuk dalam Pengadilan Negeri dilakukan oleh Pegawai Kantor PPK. Jika pihak yang berhak tidak mau menerima ganti rugi, barulah ganti rugi di konsinyasikan.

Jumlah keseluruhan ganti rugi yang dititipkan di Pengadilan Negeri adalah sebanyak 26 tanah dan dalam hal ini tim PPT dalam menjalankan praktek pengadaan tanah hingga konsinyasi berpedoman pada Undang-Undang Nomor 2 Tahun 2012 tentang Pengadaan Tanah Bagi Pembangunan Untuk Kepentingan Umum sebagai aturan pokok dan Peraturan Presiden Nomor 71 Tahun 2012 tentang Penyelenggaraan Pengadaan Tanah Bagi 
Pembangunan Untuk Kepentingan Umum beserta perubahan-perubahannya(Peraturan Presiden Nomor 71 Tahun 2012 tentang Penyelenggaraan Pengadaan Tanah Bagi Pembangunan Untuk Kepentingan Umum., 2012) dan Peraturan Mahkamah Agung Nomor 3 Tahun 2016 tentang Tata Cara Pengajuan Keberatan dan Penitipan Ganti Kerugian Ke Pengadilan Negeri Dalam Pengadaan Tanah Bagi Pembangunan untuk Kepentingan Umum sebagai aturan pelaksanaannya(Peraturan Mahkamah Agung Nomor 3 Tahun 2016 tentang Tata Cara Pengajuan Keberatan Dan Penitipan Ganti Kerugian Ke Pengadilan Negeri Dalam Pengadaan Tanah Bagi Pembangunan Untuk Kepentingan Umum, 2016).

Menurut narasumber Nizar yang merupakan panitia PPT (Pelaksana Pengadaan Tanah) yang mewakili dari Kantor PPK (Pejabat Pembuat Komitmen) yang menangani permasalahan tentang pengadaan tanah untuk kegiatan jalan tol di Kabupaten Batang, praktek dalam melakukan penitipan ganti rugi ke Pengadilan Negeri terhadap pihak yang tanahnya tidak mau dilakukan pencabutan hak telah sesuai dengan prosedur yang ada di dalam Undang-Undang Nomor 2 Tahun 2012 tentang Pengadaan Tanah Bagi Pembangunan Untuk Kepentingan Umum dan Peraturan Presiden Nomor 71 Tahun 2016 tentang Penyelenggaraan Pengadaan Tanah Bagi Pembangunan Untuk Kepentingan Umum beserta perubahan-perubahannya, serta tata cara konsinyasi yang lebih mendetail tercantum dalam Peraturan Mahkamah Agung Nomor 3 Tahun 2016 tentang Tata Cara Pengajuan Keberatan dan Penitipan Ganti Kerugian Ke Pengadilan Negeri Dalam Pengadaan Tanah Bagi Pembangunan Untuk Kepentingan Umum sebagai aturan pelaksanaannya. Melalui tahapan dari peraturan perundang-undangan tersebut maka proses konsinyasi dapat dijalankan, artinya langkah-langkah dari konsinyasi dapat terlaksana dilihat dari dasarnya terlebih dahulu yaitu Undang-Undang Nomor 2 Tahun 2012, Peraturan Presiden Nomor 71 tahun 2012 beserta perubahan-perubahannya, kemudian Peraturan Mahkamah Agung Nomor 3 Tahun 2016.

Berdasarkan hasil penelitian di atas, penulis berpendapat bahwa praktek pelaksanaan pengadaan tanah bagi pembangunan untuk kepentingan umum terkait dengan proyek pembangunan jalan tol di Kabupaten Batang sudah dilaksanakan dan disesuaikan berdasarkan Undang-Undang Nomor 2 Tahun 2012 tentang Pengadaan Tanah Bagi Pembangunan Untuk Kepentingan Umum sebagai dasar peraturan pokoknya dan Peraturan Presiden Republik Indonesia Nomor 71 Tahun 2012 tentang Penyelenggaraan Pengadaan Tanah Bagi Pembangunan Untuk Kepentingan Umum jo Peraturan Presiden Nomor 40 Tahun 2014 tentang Perubahan Atas Peraturan Presiden Nomor 71 Tahun 2012 tentang Penyelenggaraan Pengadaan Tanah Bagi Pembangunan Untuk Kepentingan umum jo 
Peraturan Presiden Nomor 99 Tahun 2014 tentang Perubahan Kedua Atas Peraturan Presiden Nomor 71 Tahun 2012 tentang Penyelenggaraan Pengadaan Tanah Bagi Pembangunan Untuk Kepentingan umum jo Peraturan Presiden Nomor 30 Tahun 2015 tentang Perubahan Ketiga Atas Peraturan Presiden Nomor 71 Tahun 2012 tentang Penyelenggaraan Pengadaan Tanah Bagi Pembangunan Untuk Kepentingan umum jo Peraturan Presiden Nomor 148 Tahun 2015 Tentang Perubahan Keempat Atas Peraturan Presiden Nomor 71 Tahun 2012 tentang Penyelenggaraan Pengadaan Tanah Bagi Pembangunan Untuk Kepentingan umum sebagai peraturan teknis pelaksanaannya, namun panitia Pelaksana Pengadaan Tanah seharusnya tidak hanya melakukan tugasnya hanya berdasarkan peraturan perundang-undangan saja, melainkan harus memperhatikan hal-hal yang tidak diatur didalam peraturan perundang-undangan mengenai kondisi yang dialami warga sehingga dapat mencapai kesepakatan dengan warga, karena pada dasarnya dalam melakukan pengadaan tanah harus tercapai kesepakatan antara pemegang hak atas tanah dengan instansi yang memerlukan tanah sesuai dengan asas kesepakatan yanag ada di dalam Pasal 2 Undang-Undang Nomor 2 Tahun 2012 tentang Pengadaan Tanah Bagi Pembangunan Untuk Kepentingan Umum sehingga tidak perlu dilakukan konsinyasi.

2. Perlindungan hukum terhadap pemegang hak atas tanah yang tanahnya diberikan ganti rugi melalui penitipan di pengadilan (konsinyasi) dalam pembangunan jalan tol di Kabupaten Batang

Berdasarkan keterangan dari narasumber Nizar, tanah yang dijadikan sebagai objek pengadaan tanah setelah dilakukannya penitipan ganti rugi (konsinyasi) dapat langsung dikerjakan untuk proyek setelah ada penetapan dari Pengadilan Negeri setempat yang telah memiliki kekuatan hukum tetap. Menurut Nizar perlindungan hukum yang didapat oleh pemegang hak atas tanah diantaranya:

1. Sebelum melakukan pelaksanaan pengadaan tanah milik warga, Panitia Pelaksana Pengadaan Tanah (PPT) telah melakukan sosialisasi kepada warga untuk memberitahukan bahwa tanahnya akan digunakan dalam proyek pembangunan untuk kepentingan umum.

2. Panitia Pelaksana Pengadaan Tanah (PPT) telah menawarkan dan memberikan ganti rugi yang layak kepada warga yang nilainya telah ditetapkan secara sepihak oleh Panitia Pelaksana Pengadaan Tanah.

3. Warga yang masih merasa keberatan mengenai jumlah nilai ganti rugi, dapat mengajukan keberatan ke Pengadilan Negeri setempat. 
Mengenai manfaat dari konsinyasi menurut narasumber Nizar selaku panitia PPT diantaranya adalah mempercepat proyek pembangunan untuk kepentingan umum yang tentunya memakan waktu yang sangat lama, tentunya hal tersebut dapat tercapai bergantung kepada keaktifan masyarakat untuk berperan dan mendukung proyek kepentingan umum jalan tol tersebut. Panitia PPT telah memberikan sosialisasi dan penyuluhan mengenai konsinyasi bahwa apabila terdapat pihak yang tidak sepakat, maka permohonan dapat langsung diajukan ke Pengadilan Negeri karena panitia PPT hanya sebagai perangkat yang menjalankan regulasi pengadaan tanah yang ada dan dilindungi oleh hukum.

Berdasarkan pernyataan diatas, maka penulis berpendapat bahwa perlindungan hukum pemegang hak atas tanah yang dilakukan oleh panitia Pelaksana Pengadaan Tanah belum memperhatikan perlindungan hukum pemegang hak atas tanah khususnya terkait dengan kepemilikan tanah, hal ini disebabkan karena pemerintah sebagai pihak yang memerlukan tanah terkesan memaksa para pihak pemegang hak atas tanah untuk melepaskan status kepemilikan tanah mereka berdasarkan musyarawarah antara pemerintah melalui Panitia Pelaksana Pengadaan Tanah (PPT) dengan para pihak pemegang hak atas tanah. Hal ini tentu bertolak belakang dengan asas kesepakatan dalam melakukan pelepasan hak atas tanah yang didasarkan pada kesepakatan kedua belah pihak yaitu panitia Pelaksana Pengadaan Tanah dengan pemegang hak atas tanah.

\section{Simpulan}

Berdasarkan hasil dan pembahasan yang ada dalam artikel jurnal ini, maka dapat diambil kesimpulan yaitu kebijakan peraturan pengadaan tanah di Indonesiasesuai dengan Pasal 6 Undang-Undang Nomor 5 Tahun 1960 tentang Peraturan Dasar Pokok-Pokok Agraria menyebutkan bahwa "Semua hak atas tanah mempunyai fungsi sosial". Maksud dari fungsi sosial disini adalah bahwa segala hak atas tanah digunakan sebesar-besarnya untuk kesejahteraan warga Negara Indonesia sehingga tanah milik masyarakat khususnya warga negara Indonesia dapat diambil alih hak kepemilikannya oleh negara. Namun para pemegang hak atas tanah menerima ganti kerugian atas tanah mereka, serta apabila para pemegang hak menolak/tidak puas dengan jumlah ganti rugi maka dapat mengajukan gugatan ke Pengadilan Negeri Batang sesuai dengan Undang-Undang Nomor 2 Tahun 2012 tentang Pengadaan Tanah Bagi Pembangunan Untuk Kepentingan Umum dan Peraturan Presiden Nomor 71 Tahun 2016 tentang Penyelenggaraan Pengadaan Tanah Bagi Pembangunan Untuk Kepentingan Umum beserta perubahan-perubahannya, serta Peraturan Mahkamah Agung Nomor 3 Tahun 2016 tentang Tata Cara Pengajuan Keberatan dan Penitipan Ganti Kerugian Ke Pengadilan Negeri 
Dalam Pengadaan Tanah Bagi Pembangunan Untuk Kepentingan Umum sebagai aturan pelaksanaannya.

Perlindungan hukum pemegang hak atas tanah belum memperhatikan aspek hak asasi manusia khususnya terkait dengan kepemilikan tanah, hal ini disebabkan karena pemerintah sebagai pihak yang memerlukan tanah terkesan bersifat memaksa kepada para pihak pemegang hak atas tanah untuk melepaskan status kepemilikan tanah mereka hanya berdasarkan musyarawarah dan belum terjadi kesepakatan antara pemerintah melalui Panitia Pelaksana Pengadaan Tanah (PPT) dengan para pihak pemegang hak atas tanah. Pemerintah lebih memperhatikan aspek nilai ganti rugi (kompensasi) yang diterima para pemegang hak atas tanah. Pihak pemegang hak atas tanah dapat mengajukan permohonan keberatan ke Pengadilan Negeri apabila tidak sepakat dalam pemberian ganti rugi yang didasarkan pada Peraturan Mahkamah Agung Nomor 3 Tahun 2016 tentang Tata Cara Pengajuan Keberatan dan Penitipan Ganti Kerugian Ke Pengadilan Negeri Dalam Pengadaan Tanah Bagi Pembangunan Untuk Kepentingan Umum. Dalam aspek hukum pertanahan sudah mengatur mengenai perlindungan hukum bagi pemegang hak atas tanah, namun pelaksanaannya pemerintah belum memberikan perlindungan hukum dengan baik kepada pemegang hak atas tanah yang tanahnya digunakan dalam kegiatan pembangunan untuk kepentingan umum.

\section{DAFTAR PUSTAKA}

\section{Buku :}

Andorra, H. (2016). Aktualisasi Nilai-Nilai Pancasila Dalam Pengadaan Tanah Bagi Pembangunan Untuk Kepentingan Umum. Masalah-Masalah Hukum, 45, 19.

Chomzah, A. A. (2002). Hukum Pertanahan. Jakarta: Prestasi Pustaka.

Hadjon, M. P. (1987). Perlindungan Hukum Bagi Rakyat Di Indonesia. Yogyakarta: Bina Ilmu.

Hermit, H. (2007). Cara Memperoleh Sertifikat Tanah Wakaf. Bandung: Mandar Maju.

Limbong, B. (2011). Pengadaan Tanah Untuk Pembangunan. Jakarta: Pustaka Margaretha.

Mertokusumo, S. (2010). Bunga Rampai Ilmu Hukum. Yogyakarta: Liberty.

Raharjo, S. (2000). Ilmu Hukum. Bandung: Citra Aditya Bakti.

Raharjo, S. (2004). Ilmu Hukum: Pencarian, Pembebasan, dan Pencerahan. Surakarta: Muhammadiyah University Press.

Rawls, J. (1971). Teori Keadilan: Dasar-dasar Filsafat Politik Untuk Mewujudkan Kesejahteraan Sosial Dalam Negara. Jakarta: Pustaka Pelajar. 
Soekanto, S. (1986). Pengantar Penelitian Hukum. Jakarta: UI Press.

Sumardjono, Maria S.W dan Ismail, N. dan I. (2008). Mendiasi Sengketa Tanah. Jakarta: Kompas.

\section{Artikel Jurnal :}

Permatasari, M. dan S. (2019). Penyelesaian Sengketa Pengadaan Tanah Guna Pembangunan Bandar Udara Internasional Berbasis Nilai Keadilan Sosial. Notarius, 12, 16.

Wulandari, R. Y. (2018). Pengadaan Tanah dan Pelaksanaan Pemberian Ganti Rugi Untuk Proyek Pembangunan Pasar Kebon Roek Di Kota Mataram. Notarius, 20, 18.

Yusrizal, M. (2017). Perlindungan Hukum Pemegang Hak Atas Tanah Dalam Pengadaan Tanah Untuk Kepentingan Umum. De Lega Lata, 2, 26.

\section{Undang-undang dan Peraturan :}

Undang-Undang Dasar Negara Republik Indonesia. , (1945).

Undang-Undang Nomor 2 Tahun 2012 tentang Pengadaan Tanah Bagi Pembangunan Untuk Kepentingan Umum., Pub. L. No. 2, 48 (2012).

Undang-Undang Pokok Agraria Nomor 5 tahun 1960 tentang Peraturan Dasar Pokok-Pokok Agraria. , Pub. L. No. 5, 109 (1960)

Peraturan Mahkamah Agung Nomor 3 Tahun 2016 tentang Tata Cara Pengajuan Keberatan Dan Penitipan Ganti Kerugian Ke Pengadilan Negeri Dalam Pengadaan Tanah Bagi Pembangunan Untuk Kepentingan Umum., Pub. L. No. 3, 47 (2016).

Peraturan Presiden Nomor 71 Tahun 2012 tentang Penyelenggaraan Pengadaan Tanah Bagi Pembangunan Untuk Kepentingan Umum. , Pub. L. No. 71, 27 (2012). 